\title{
PERANCANGAN APLIKASI PERHITUNGAN BANGUN DATAR DAN BANGUN RUANG BERBASIS ANDROID
}

\author{
Hayyillah Al Marzuki ${ }^{1}$, Wahyu Nur Cholifah ${ }^{2}$, Mukhamad Candra Irawan ${ }^{3}$ \\ Informatika, Universitas Indraprasta PGRI \\ alzhuky95@gmail.com¹,wnurcholifah@gmail.com ${ }^{2}$, tiunidra.fisika@gmail.com³
}

Submitted October 5, 2019; Revised November 20, 2019; Accepted November 25, 2019

\begin{abstract}
Abstrak
Tujuan yang akan dicapai dalam penelitian ini adalah membuat aplikasi android yang membantu pelajar untuk menghitung dan belajar tentang bangun datar dan bangun ruang. Aplikasi ini merupakan aplikasi untuk menghitung luas, keliling, dan volume suatu bangun datar ataupun bangun ruang dengan berbasiskan OS Android yang didalamnya juga terdapat gambar, rumus, serta materi yang menyangkut tentang penghitungan geometri tersebut. Pengguna memilih bangun apa yang akan dihitung, kemudian memasukkan input yang diminta dalam melakukan penghitungan. Dalam perancangan dan pembuatan aplikasi ini diperlukan software yaitu Java, Android ADT, dan Photoshop.
\end{abstract}

Kata Kunci: Android, Bangun Datar, Bangun Ruang, Penghitung.

\begin{abstract}
Abtract
The goal to be achieved in this research is to create an android application that helps students to calculate and learn about getting up flat and getting up space. This application is an application for calculating the area, perimeter, and volume of a flat shape or space building based on the Android OS which includes images, formulas, and material related to the calculation of the geometry. The user chooses to build what is to be counted, then enters the input requested in the calculation. In designing and making this application required software, namely Java, Android ADT, and Photoshop.

Keywords: Android, Build Flat, Build Space, Counters.
\end{abstract}

\section{PENDAHULUAN}

Seiring berjalannya waktu, teknologi informasi yang semakin canggih dan juga dunia semakin maju. Teknologi merupakan salah satu hal yang tidak mudah dilepaskan dari kehidupan manusia. Karena teknologi sudah ada sejak berabad-abad lalu dan hingga kini masih terus berkembang. Tanpa adanya teknologi manusia tentunya akan sulit untuk melakukan komunikasi dan menyampaikan informasi. Salah satu teknologi saat ini berkembang pesat di dunia yaitu teknologi berbasis mobile.

Mobile Application di jaman modern ini sangat dibutuhkan dari segala bidang, seperti bidang industri, kuliner, pertanian, perikanan dan sebagainya. Begitu pula dalam dunia pendidikan. Dalam dunia pendidikan mobile application ini menjadi suatu terobosan baru dan inovatif. Karena dapat mempermudah dan menjadi daya tarik belajar siswa. Khusus dalam pembelajaran bangun datar dan bangun ruang.

Pembelajaran bangun datar dan bangun ruang merupakan salah satu materi dalam matematika yang memuat prinsip hitungan, sehingga memerlukan pemahaman lebih. Hal itu akan membuat para siswa merasa jenuh dan bosan dalam menerima materi pembelajaran. Dengan semakin berkembangnya teknologi khususnya di bidang multimedia dapat dimanfaatkan sebagai media pembelajaran siswa. [4] 
Tujuan dari penelitian ini yaitu:

1) Membuat aplikasi berbasis android yang dapat menambah minat belajar siswa khusus materi bangun datar dan bangun ruang.

2) Merancang suatu aplikasi bangun datar dan bangun ruang yang sesuai yang dibutuhkan siswa.

3) Memudahkan siswa dalam menghitung luas, keliling, luas permukaan dan volume pada bangun datar dan bangun ruang.

Adapun Manfaat dari penelitian ini yaitu:

1) Memberikan kemudahan dalam pemahaman siswa materi tentang bangun datar dan bangun ruang.

2) Meningkatkan minat belajar siswa dalam mempelajari bangun datar dan bangun ruang.

3) Memberikan kemudahan dalam menghitung luas, keliling, luas permukaan dan volume bangun datar dan bangun ruang.

\section{METODE PENELITIAN}

\section{Metode Penelitian}

Metode Penelitian dimulai dari mengindentifikasi kebutuhan sistem yang akan dibuat, implementasi sistem kerja uji coba sistem. Metode penelitian yang digunakan adalah metode System Development Life Cycle (SDLC). Metode ini merupakan sebuah siklus yang membangun suatu sistem itu sendiri dan memberikannya kepada pengguna melalui tahapan perencanaan, analisa perancangan dan implementasi dengan cara memahami dan menyeleksi keadaan dan proses yang dilakukan pengguna untuk dapat mendukung seluruh kebutuhan para pengguna. Untuk menggunakan SDLC, maka dibutuhkan sumber dari data awal tersebut dari pengguna yang dijadikan acuan nantinya dimasukkan kedalam perencanaan, analisa, perancangan dan implementasi [2].
Penelitian adalah sebuah proses kegiatan yang bertujuan untuk mengetahui sesuatu secara teliti, kritis dalam mencari faktafakta dengan menggunakan langkahlangkah tertentu. Keinginan untuk mengetahui sesuatu tersebut secara teliti, muncul karena adanya suatu masalah yang membutuhkan jawaban yang benar [5].

Penelitian juga merupakan suatu proses yang bertujuan untuk menemukan, mengembangkan dan menguji suatu pengetahuan dengan cara mengumpulkan, mencatat, menganalisis informasi data yang dilakukan dengan sabar, hati-hati, terencana dan sistematis serta berdasarkan ilmu pengetahuan [3].

Saat berjalannya penelitian bukan hanya mencari dan mengumpulkan data, tetapi juga langsung melakukan klasifikasi data tersebut, mengolah dan menganalisa data, membangun hipotesis menjadi teori serta menulis laporan dari waktu ke waktu.

Metode pengumpulan data yang dilakukan oleh penulis untuk mendapatkan data-data serta informasi untuk mendukung penyempurnaan dari pembuatan Perancangan Aplikasi Perhitungan Bangun Datar dan Bangun Ruang Berbasis Android yang penulis buat antara lain [1]:

\section{1) Studi Kepustakaan}

Pengumpulan data dan informasi diambil dari kutipan-kutipan buku-buku, peraturang perundang-undangan, serta hasil laporan dari bahan lainnya yang berkaitan dengan penelitian ini. Dari bahan-bahan tersebut diambil teori-teori yang dapat dijadikan landasan untuk menganalisa masalah yang ditemukan dalam penelitian.

Studi kepustakan bertujuan untuk mempelajari dan memahami dasar teori yang berhubungan dengan analisan kebutuhan yang telah dilakukan. Selain itu, penulis juga melakukan studi dari berbagai media yang berupa buku-buku ataupun artikel-artikel baik dari internet maupun 
media cetak untuk menunjang demi terselesaikannya tugas akhir ini [1].

\section{2) Studi Observasi}

Studi lapangan ini penulis lakukan dengan memberikan pertanyaan langsung dan memberikan aplikasi android bangun datar dan bangun ruang kepada siswa. Setelah itu meminta siswa untuk mengoperasikan aplikasi tersebut. Studi lapangan ini ditunjukkan untuk mengetahui seberapa besar pengetahuan mereka dan apakah aplikasi tersbut mudah bagi siswa untuk dioperasikan dalam mempelajari bangun datar dan bangun ruang. Agar penulis dapat membantu mengimplementasikan metode pembelajaran yang berbeda dan dapat memudahkan siswa/i belajar dengan media aplikasi android [1].

\section{Langkah-Langkah Pengembangan Sistem}

Dalam proses penyempurnaan hasil dari pencarian data atau informasi, penulis mencoba menuliskan langkah-langkah yang dilakukan dalam mengembangkan sebuah aplikasi. Langkah-langkah yang dilakukan pada tahap ini adalah:

\section{1) Identifikasi Masalah}

Identifikasi masalah adalah tahap permulaan dari penguasaan masalah dimana objek dalam suatu jalinan tertentu bisa dikenali sebagai suatu masalah. Proses ini merupakan hal yang terpenting dalam sebuah penelitian, bahkan suatu kegiatan tidak dikatakan sebagai sebuah penelitian jika identifikasi masalah yang dibuat tidak sesuai fakta.

\section{2) Analisa dan Pengumpulan Data}

Analisa perancangan berguna untuk mendapatkan data-data yang akan digunakan sebagai masukan dari suatu sistem dan untuk memperoleh data yang berhubungan dengan penelitian ini. Proses perancangan aplikasi Perhitungan Bangun Datar dan Bangun Ruang Berbasis Android yang penulis buat, dimulai dari memahami siswa. Sebelum merancang sebuah sistem kita harus memahami kebutuhan siswa, bagaimana cara yang memudahan siswa dalam memahami pembelajaran di Sekolah.

\section{3) Studi Kepustakaan}

Studi Kepustakaan merupakan kegiatan mengumpulkan data-data berupa teori pendukung dari sistem yang dibuat dengan maksud untuk memaparkan tentang teori tersebut.

\section{4) Perancangan Aplikasi}

Perancangan Aplikasi bertujuan untuk merancang aplikasi yang akan dibuat agar dapat diimplementasikan dengan kebutuhan siswa.

\section{5) Pembuatan Aplikasi}

Pembuatan aplikasi adalah proses selanjutnya dari tahap perancangan aplikasi. Setelah beberapa langkah yang ada pada tahap perancangan aplikasi, maka dilakukan pengkodean (coding) untuk membuat aplikasi tersebut. Aplikasi yang dibuat harus memudahkan siswa dalam menggunakan aplikasi tersebut agar kegunaan dari aplikasi ini dapat dicapai dengan baik dan maksimal.

\section{6) Implementasi dan Pengujian}

Implementasi dan pengujian adalah proses menterjemahkan dokumen hasil desain menjadi perintah bahasa pemrograman komputer. Semakin baik hasil analisis dan desain yang dilakukan. Pengujian juga bertujuan untuk bahan evaluasi bagi penulis, jika masih terdapat masalah yang dihadapi dalam penggunaan aplikasi Perhitungan Bangun Datar dan Bangun Ruang ini.

\section{HASIL DAN PEMBAHASAN}

\section{Hasil Perancangan}

Aplikasi perhitungan bangun datar dan bangun ruang dibuat menggunakan Android Studio 3.42. Aplikasi ini dirancang untuk mempermudah siswa dalam mempelajari perhitungan bangun 
datar dan bangun ruang. Aplikasi ini dibuat semenarik dan semudah mungkin yang hanya menampilkan gambar dan rumus, namun juga dapat melakukan proses perhitungan. Aplikasi ini juga dapat diakses tanpa menggunakan internet (offline). Dengan adanya aplikasi ini diharapkan dapat memudahkan siswa untuk mempelajari dan menguasai materi perhitungan khususnya bangun datar dan bangun ruang. Flowchart menu awal yang dirancang pada aplikasi perhitungan bangun datar dan bangun ruang yang dibuat pada gambar 1 .

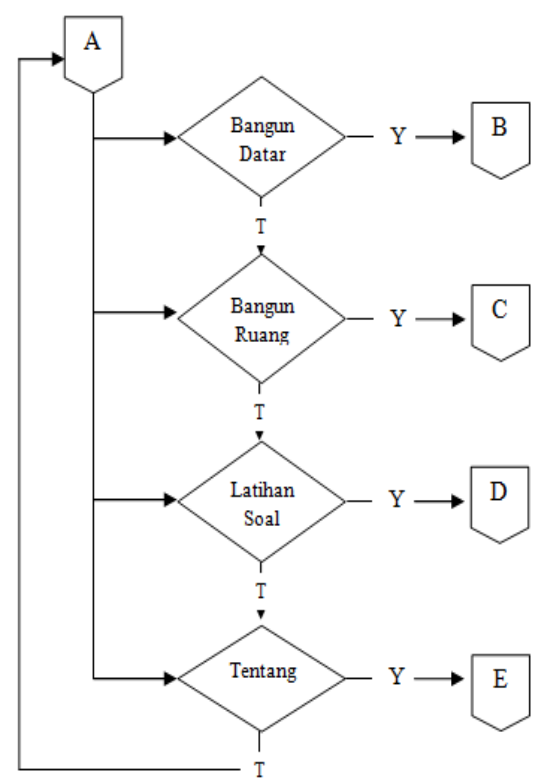

Gambar 1. Flowchart Menu Utama Aplikasi

Pada Flowchart Menu Utama ini terdapat 4 (empat) menu pilihan yang masing-masing memiliki fungsi tersendiri. Data keluarannya (output) berupa informasi yang meliputi:

a) Pilih Menu Bangun Datar di menu bangun datar ini ada 8 sub menu pilihan yaitu persegi, persegi panjang, segitiga, jajar genjang, belah ketupat, layanglayang, trapesium dan lingkaran. Jika pengguna memilih salah satu sub menu tersebut maka aplikasi akan dialihkan ke tampilan perhitungan. b) Pilih Menu Bangun Ruang di menu bangun ruang ini ada 7 sub menu pilihan yaitu kubus, balok, limas, prisma, tabung, kerucut dan bola. Jika pengguna memilih salah satu sub menu tersebut maka aplikasi akan dialihkan ke tampilan perhitungan.

c) Pilih Menu Latihan Soal di menu ini akan menampilkan soal-soal bangun datar dan bangun ruang. Jika pengguna menjawab soal-soal tersebut hingga selesai maka akan muncul total nilai/ score yang di peroleh sesuai menjawab soal dengan benar.

d) Pilih Tentang di menu ini berisi tentang biodata dan jika menekan biodata tersebut akan mengeluarkan audio suara pembuat aplikasi.

\section{Penggunaan Program}

Penggunaan program aplikasi ini pada perangkat nyata yaitu laptop yang telah didukung teknologi Android. Untuk dapat melakukan uji coba dari aplikasi ini diperlukan perangkat lunak pendukung yang akan menjadi media untuk menjalankan aplikasi yaitu: Android studio versi 3.42 dan Smartphone Android versi Ice Cream Sandwich.

Aplikasi perhitungan bangun datar dan bangun ruang lewat multimedia ini juga dapat dijalankan pada Smartphone android dengan minimal versi Android Ice Cream Sandwich. Penggunaan program manual book aplikasi ini yaitu:

a) Buka file bangun datar dan bangun ruang, apk pada smartphone Android.

b) Setelah file bangun datar dan bangun ruang, apk dibuat maka akan tampil pilihan aplikasi, pilih package installer.

c) Buka aplikasi perhitungan bangun datar dan bangun ruang di Smartphone. Tunggu tampilan splash screen. Lalu akan muncul menu awal, pilih button masuk untuk melanjutkan ke Menu Utama. Setelah Menu Utama terbuka, pilih salah satu (menu) di dashboard yang akan dijalankan. 


\section{Implementasi Program}

Hasil uang dicapai dalam penelitian ini adalah aplikasi pembelajaran bangun datar dan bangun ruang berbasis android yaitu sebagai berikut.

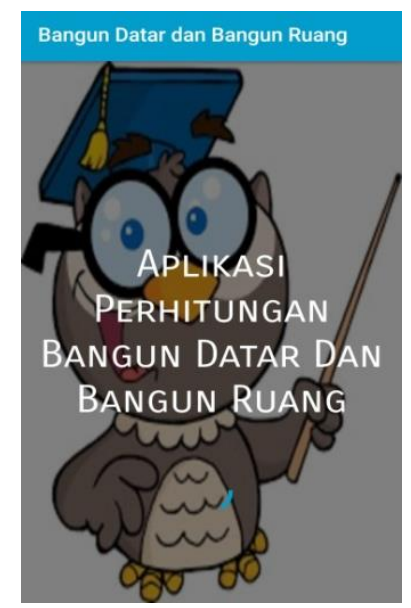

\section{Gambar 2. Tampilan Loading}

Tampilan awal menu dari aplikasi perhitungan bangun datar dan bangun ruang. Dalam menu ini terdapat 4 menu utama yaitu Bangun datar, Bangun ruang, Latihan soal, dan Tentang.

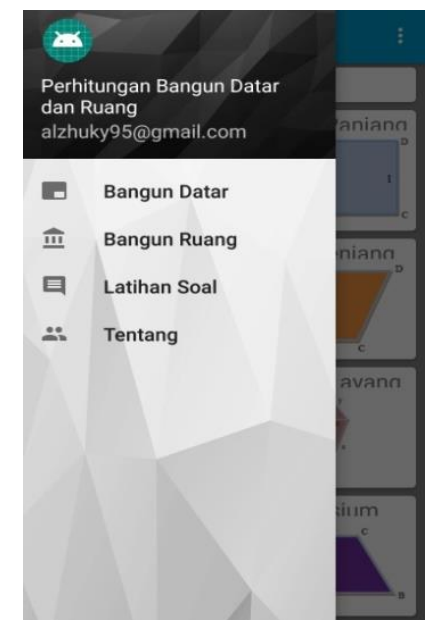

\section{Gambar 3. Tampilan Menu Pilihan}

Tampilan ini berisi 8 sub menu bangun datar yaitu persegi, persegi panjang, segitiga, jajar genjang, belah ketupat, layang-layang, trapesium dan lingkaran.
Pengguna aplikasi dapat menekan gambar bentuk bangun datar yang dipilih.

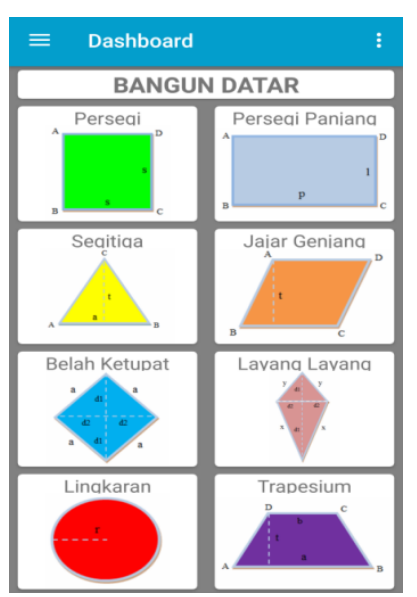

\section{Gambar 4. Tampilan Menu Bangun Datar}

Tampilan ini merupakan halaman salah satu dari sub menu bangun datar. Tampilan ini berisi rumus keliling dan luas bangun datar yang dipilih, serta melakukan perhitungan keliling dan luas. Untuk melakukan perhitungan masukkan nilai dan pilih perhitungan yang diinginkan.

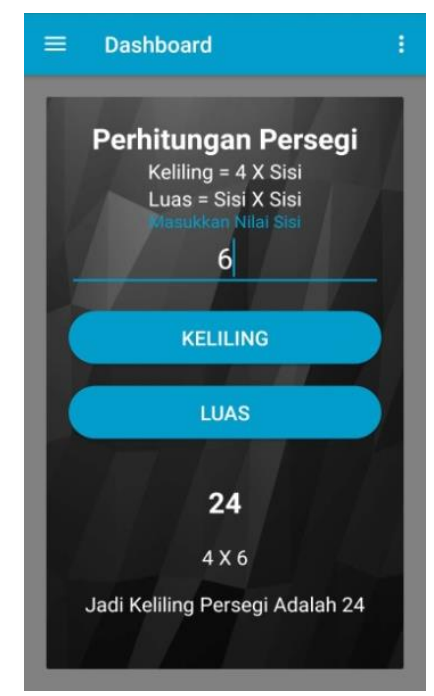

\section{Gambar 5. Tampilan Perhitungan Bangun Datar}

Tampilan ini berisi 7 sub menu bangun ruang yaitu kubus, balok, limas, prisma, kerucut, tabung dan bola. Pengguna 
aplikasi dapat menekan gambar bentuk bangun ruang yang dipilih.

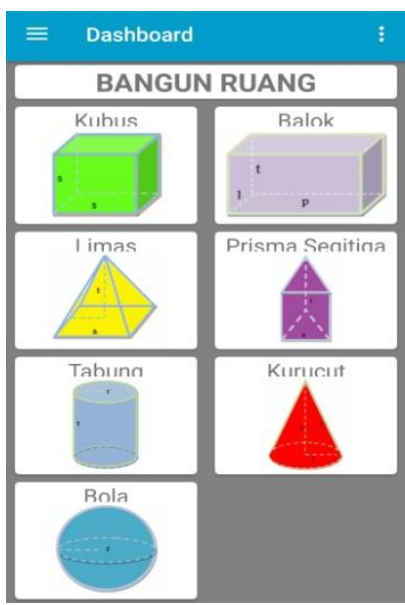

\section{Gambar 6. Tampilan Menu Bangun Ruang}

Tampilan ini merupakan halaman salah satu dari sub menu bangun datar. Tampilan ini berisi rumus luas permukaan dan volume bangun ruang yang dipilih, serta melakukan perhitungan luas permukaan dan volume. Untuk melakukan perhitungan masukkan nilai dan pilih perhitungan yang diinginkan.

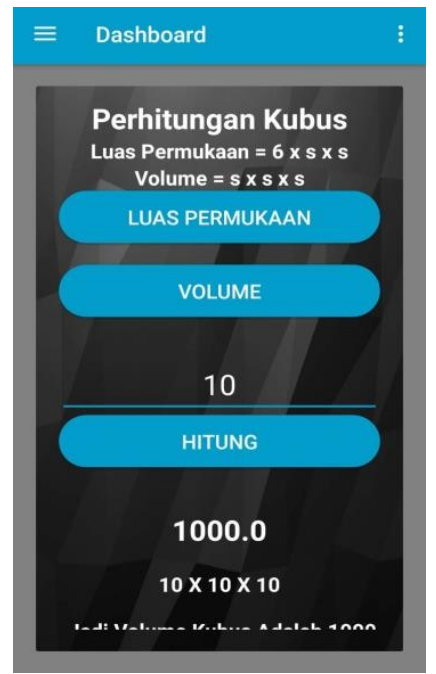

\section{Gambar 7. Tampilan Perhitungan Bangun Ruang}

Tampilan ini merupakan latihan soal awal yang dapat dikerjakan dibantu dengan adanya jawaban pilhan ganda. Tampilan ini berisi 10 soal, latihan soal akhir yang harus diselesaikan untuk mendapatkan nilai atau skor akhir. Ketika memilih jawaban akan muncul suara pemberitahuan salah atau benar. Setelah menyelesaikan semua soal dan dijawab lalu akan mendapat hasil nilai/ skor akhir.

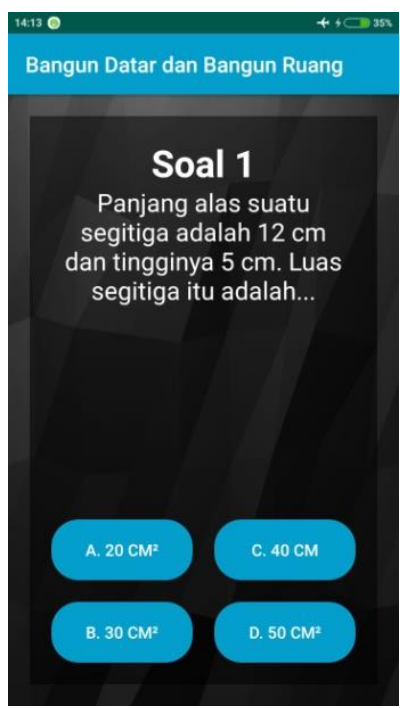

Gambar 8. Tampilan Latihan Soal Awal

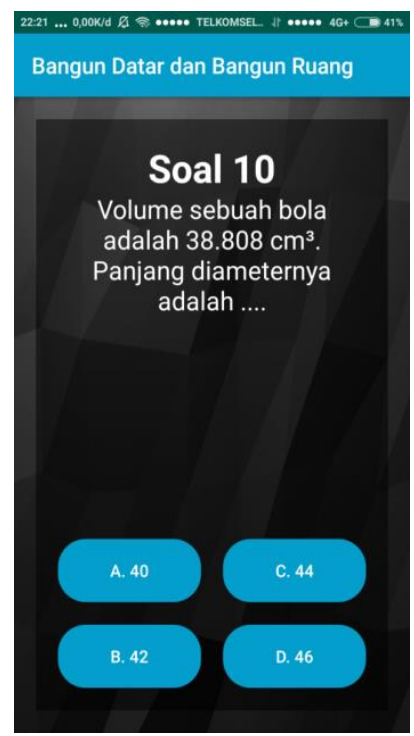

\section{Gambar 9. Tampilan Latihan Soal Akhir}

Tampilan ini muncul setelah menyelesaikan semua soal dan dijawab lalu akan mendapat hasil nilai/ skor akhir seperti gambar 10. Lalu jika di pilih 
kembali maka aplikasi akan ke menu utama

\section{DAFTAR PUSTAKA}

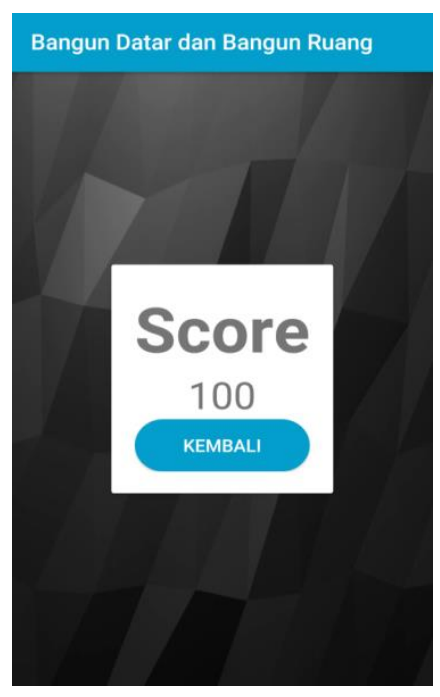

Gambar 10. Tampilan Skor Akhir

\section{SIMPULAN}

Perancangan Aplikasi Perhitungan Bangun Datar dan Bangun Ruang Berbasis Android menjadi langkah awal untuk memudahkan dan meningkatkan daya tarik pembelajaran siswa dalam materi tersebut. Berdasarkan pembahasan pada hasil analisa yang telah dilakukan maka simpulan yang dapat diambil antaranya:

a) Pengembangan aplikasi bangun datar dan bangun ruang dengan menambahkan fitur perhitungan luas, keliling, luas permukaan, volume bangun datar dan bangun ruang.

b) Adanya aplikasi ini memberikan kemudahan dan meningkatkan daya tarik belajar siswa serta lebih efektif karena tampilan dan desain aplikasi yang menarik dengan adanya fitur perhitungan yang dapat memudahkan siswa belajar tanpa takut salah dalam menghitung luas, keliling, luas permukaan, volume bangun datar dan bangun ruang.
[1] Desmira, Aribowo, D., \& Oktavia, P. (2014). Perancangan Aplikasi Pembelajaran Bangun Datar Dan Ruang Untuk Sekolah Dasar Menggunakan Android. Prosisko, 1(September), 48-54.

[2] Firmansyah, Y., \& Udi, U. (2017). Penerapan Metode SDLC Waterfall Dalam Pembuatan Sistem Informasi Akademik Berbasis Web Studi Kasus Pondok Pesantren Al-Habib Sholeh Kabupaten Kubu Raya, Kalimantan Barat. Jurnal Teknologi Dan Manajemen Informatika, 4(1).

[3] Fitriyah, S., Utami, D. T., \& Kusnawi, K. (2015). Perancangan Aplikasi Matematika Kontekstual Pada Materi Geometri 3 Dimensi Berbasis Java Untuk Smp Islam Al Azhar 26 Yogyakarta. Data Manajemen Dan Teknologi Informasi (DASI), 16(1), 55.

[4] Marlina, E., \& Fatmasari. (2016). Perancangan Aplikasi Pembelajaran Matematika Dengan Rumus Bangun Datar Dan Ruang Untuk Siswa SMP Frater Makassar. Semnasteknomedia Online, 4(1), 19-24.

[5] Mulyadi, M. (2013). Penelitian Kuantitatif Dan Kualitatif Serta Pemikiran Dasar Menggabungkannya. Jurnal Studi Komunikasi Dan Media, 15(1), 128. 